\title{
TECHNOLOGICAL CHARACTERISTICS OF CHICKPEA (Cicer arietinum L.) CULTIVARS GROWN UNDER NATURAL CONDITIONS
}

\author{
Hamdi OZAKTAN ${ }^{*}$ \\ ${ }^{I}$ Erciyes University, Faculty of Agriculture, Department of Field Crops, Kayseri, TURKEY \\ *Corresponding author: ozaktan_03@hotmail.com
}

Received: 03.11.2021

\begin{abstract}
Technological characteristics (dry weight, dry volume, wet weight, wet volume, water absorption capacity, water absorption index, hydration coefficient, swelling capacity, swelling index, cooking time, number of destructed seeds after cooking) of 27 chickpea cultivars grown under natural conditions (without the use of chemical/organic fertilizers) were investigated in this study. Except for water absorption index and hydration coefficients, effects of cultivars on investigated characteristics were found to be significant. The wet weight, wet volume and water absorption capacity characteristics on PC1 explained $49.33 \%$ of total variation and swelling capacity, swelling index and unit weight characteristics on PC2 explained $25.79 \%$ of total variation (both explaining $\mathbf{7 5 . 1 2 \%}$ of total variation). Dry weight had highly significant positive correlations with wet weight $(r=0.9776)$, wet volume $(r=0.9653)$ and water absorption capacity $(r=0.9317)$. In terms of investigated characteristics, cultivars were clustered under three groups in scatter plot and dendrogram was composed of three sub-clusters under two main clusters.
\end{abstract}

Key words: Chickpea, Cooking time, Hydration coefficient, Natural conditions, Technological characteristics.

\section{INTRODUCTION}

Edible legumes constitute an important source of protein in nutrition and daily diets of millions of people worldwide (Ramakrishna et al., 2006). Protein ratios of legume grains vary between $17-40 \%$. Such ratios vary between $7-13 \%$ in cereal grains and between $18-25 \%$ in meat (de Almeida Costa et al., 2006). A hundred grams of raw chickpea (Cicer arietinum L.) kernels contain 357 calorie, 4.5-15.69\% moisture, 14.9-24.6 g protein, 0.8$6.4 \%$ oil, $2.1-11.7 \mathrm{~g}$ fiber and $2.0-4.8 \mathrm{~g}$ ash (Bibi et al., 2007). Chickpea was reported as an important tool in prevention of bronchitis, cholera and constipation. Besides, regular consumption of legumes like chickpea may prevent diabetes and reduce the risk of heart diseases (Jukanti et al., 2012). Therefore, among the legumes, chickpea is considered to be the most hypercholesteremic agent (ZiaUl-Haq et al., 2007). In terms of world productions, chickpea has the third place among edible legumes after beans and peas. Chickpea seeds exhibit changes in shape, size and color based on cultivars. Therefore, based on seed color and geographical distribution, chickpeas are divided into two types as of desi (India-originated) and kabuli (Mediterranean and Central Asia-originated) types. Kabuli chickpeas are large with white and cream seed coat color. Desi chickpeas on the other hand are small with reticulated surface and brown, black or green seed coat color (Chavan et al., 1987). Besides differences in seeds, various other factors including cooking time, cultivar characteristics, location, soil properties, environmental factors and storage conditions influence cooking quality of chickpeas (Wang et al., 2017). Cooking times of chickpea varies between 55 200 minutes (Williams et al., 1983) and cooking times of kabuli chickpeas vary between 33-72 minutes (Ozer et al., 2010). Cooking time is an inherited attribute and exhibits large variations among the cultivars. Long cooking time is considered as a significant disadvantage limiting the potential use of edible legumes (Kaur et al., 2005). The pulses with high hydration and swelling coefficients cook in a shorter time, thus they are more suitable for consumer demands (Bishnoi and Khetarpaul, 1993). While assessing technological characteristics of the pulse cultivars, generally high wet weight, wet volume, water absorption capacity, water absorption index, swelling capacity and swelling index and short cooking time are desired (Gulumser et al., 2008).

In this study, technological characteristics of 27 chickpea cultivars, registered by public and private organizations of Turkey grown under naturel conditions without using chemical fertilizers, were investigated.

\section{MATERIALS AND METHODS}

\section{Climate of the study area}

Monthly average temperature $\left({ }^{\circ} \mathrm{C}\right)$, relative humidity (\%) and precipitations of the experimental years and longterm averages are shown in Table 1. 
Table 1. Climate data for experimental years (2018 and 2019) and long-term (1931 - 2019) averages

\begin{tabular}{|c|c|c|c|c|c|c|c|c|c|}
\hline \multirow[b]{2}{*}{ Months } & \multicolumn{3}{|c|}{$\begin{array}{c}\text { Monthly average temperature } \\
\left({ }^{\circ} \mathrm{C}\right)\end{array}$} & \multicolumn{3}{|c|}{$\begin{array}{c}\text { Monthly average relative humidity } \\
(\%)\end{array}$} & \multicolumn{3}{|c|}{$\begin{array}{c}\text { Monthly total precipitation } \\
(\mathrm{mm})\end{array}$} \\
\hline & 2018 & 2019 & 1931-2019 & 2018 & 2019 & 1931-2019 & 2018 & 2019 & 1931-2019 \\
\hline January & 1.2 & -0.8 & -1.6 & 81.9 & 74.8 & 76.6 & 73.6 & 50.7 & 35.9 \\
\hline February & 5.5 & 3.3 & 0.2 & 66.6 & 66.7 & 73.7 & 16.5 & 23.5 & 35.8 \\
\hline March & 10 & 5.6 & 4.8 & 61.2 & 59.3 & 67.9 & 100.4 & 23.1 & 42.4 \\
\hline April & 12.7 & 9.2 & 10.5 & 51.7 & 66.4 & 62.1 & 21.4 & 35.5 & 51.3 \\
\hline May & 16.7 & 17.4 & 15.0 & 61.2 & 50.2 & 61.0 & 51.9 & 23.7 & 51.5 \\
\hline June & 20.4 & 21.3 & 19.0 & 56.7 & 55.8 & 55.8 & 78.8 & 55.2 & 40.2 \\
\hline July & 24.1 & 21.6 & 22.2 & 45 & 49.1 & 49.3 & 0.6 & 35.9 & 10.6 \\
\hline August & 22.9 & 22.3 & 22.0 & 42.3 & 50.3 & 49.1 & - & 12.1 & 8.7 \\
\hline September & 19.2 & 17.4 & 17.4 & 45.5 & 51.2 & 53.7 & 2.9 & 10.6 & 14.5 \\
\hline October & 13.2 & 14.4 & 11.8 & 62.8 & 59.6 & 63.4 & 40.0 & 33.7 & 28.0 \\
\hline November & 6.8 & 7.1 & 5.5 & 69.6 & 58.8 & 71.4 & 18.2 & 20.5 & 32.1 \\
\hline December & 6.0 & 3.0 & 0.6 & 76.9 & 78.9 & 77.1 & 1.7 & 38.4 & 37.5 \\
\hline Total & 158.7 & 141.8 & - & 721.4 & 721.1 & - & 406 & 362.9 & - \\
\hline Average & 13.2 & 11.8 & 10.6 & 60.1 & 60.1 & 63.4 & 36.9 & 30.2 & 32.4 \\
\hline
\end{tabular}

*Data were supplied from Kayseri Provincial Directorate of Meteorology

In the first year, average temperatures during the vegetation period (March-September) were greater than the long-term averages and relative humidity values were relatively lower than the long-term averages. In the second year, monthly average temperatures varied between 5.6 $22.3{ }^{\circ} \mathrm{C}$ and monthly average relative humidity values varied between 49.1 and $66.4 \%$. Total precipitation throughout the vegetation period was measured as $256 \mathrm{~mm}$ in the first year, $196.1 \mathrm{~mm}$ in the second year and long-term average was $219.2 \mathrm{~mm}$. Precipitations especially in June,
July and August of the second year prolonged the vegetation duration of chickpea.

\section{Soil characteristics of the study area}

Before to set up the experiments, soil samples were taken from $0-30 \mathrm{~cm}$ soil profile of different points as to represent the study area. Soil samples were sieved through $2 \mathrm{~mm}$ sieve and analyzed for different traits. Analyses results are provided in Table 2.

Table 2. Soil physico-chemical characteristics of the study area

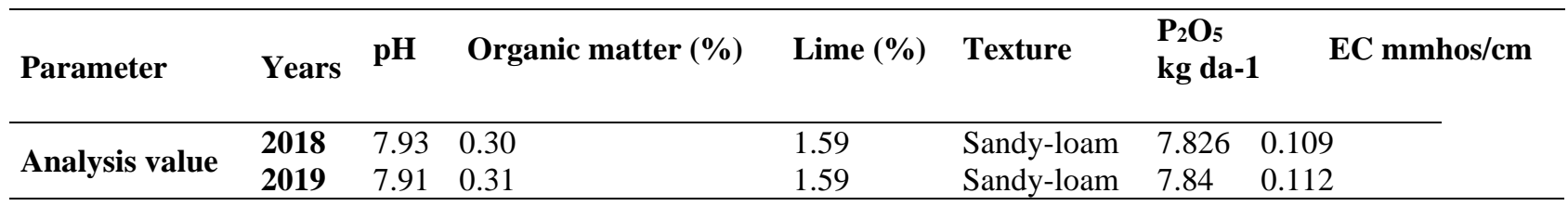

Experimental soils were sandy-loam in texture. Available phosphorus levels of the experimental soils varied between $6.785-7.826 \mathrm{~kg} \mathrm{da}^{-1}$.

In present experiments, 27 kabuli chickpea registered varieties (Akca, Akcin 91, Aksu, Aziziye 94, Azkan, Cevdetbey 98, Cagatay, Cakır, Damla 89, Dikbas, Er 99, Gokce, Gulumser, Hasanbey, Ilgaz, Isık 05, Inci, Izmir 92 , Kusmen 99, Menemen 92, Osmanbey, Sar1 98, Seckin, Sezenbey, Uzunlu 99, Yasa 05 and Zuhal) in Turkey were used as the plant material. But registration information regarding the Osmanbey variety could not be reached.

\section{Method}

Cultivars were sown in 2018 and 2019 growing seasons over the experimental fields of Erciyes University Agricultural Research and Implementation Center in randomized blocks design (RCBD) with 3 replications. Experimental plots had 6 plant rows with $30 \mathrm{~cm}$ row spacing and $5 \mathrm{~cm}$ on-row plant spacing. Experiments were set up over the fields where agricultural activities were not practiced for couple years. Neither chemical nor organic fertilizers were applied throughout both growing seasons and present observations and data will have contributions to organic-farming practicing farmers. But since the present cultivars are sensitive to anthracnose and disease Incidence is encountered suddenly and it is hard to get organic control agents instantly, two fungicide treatments were practiced throughout the entire growing season.

\section{Technological characteristics}

Dry weight, wet weight, water absorption capacity, water absorption index, dry volume, wet volume, swelling capacity, swelling index and cooking time were determined in accordance with the methods specified by Gulumser et al. (2008); hydration coefficient, with Savage et al. (2001), unit weight with Singh et al. (2010) by using the following equations.

1. Dry weight (g): A hundred seeds were randomly selected from each plot and weighed to get dry weight.

2. Wet weight (g): About $150 \mathrm{ml}$ distilled water was placed into an Erlenmeyer, then 100 seeds were placed into 
the water and kept in water for 16 hours. Seeds were removed from the water, roughly dried with drying paper and weighed to get wet weight. Later on, these samples were used in determination of cooking time.

\section{Water absorption capacity $\left(\mathrm{g} \mathrm{seed}^{-1}\right)$ :}

\section{Water absoription capacity (g kernel - 1)}

$$
=\frac{(\text { Wet weight }- \text { Dryweight })}{100-\text { number of non }- \text { swelling seeds }}
$$

\section{Water absorption index (\%)}

Water absorption index (\%) = $\underline{\text { Swelling capacity }(\mathrm{g} / \mathrm{seed})}$

(Dry weight/100)

5. Dry volume (ml): Hundred (100) seeds were placed into 100 mil cylinder. Then distilled water was added into the cylinder and the added value was subtracted from the recorded value to get dry volume.

6. Wet volume (ml): Hundred (100) seed samples were placed into $250 \mathrm{~mL}$ Erlenmeyer and then supplemented with $100 \mathrm{ml}$ distilled water. Samples were kept in water for 16 hours. Seeds were removed from the water, roughly dried with drying paper. Then the samples were placed into $250 \mathrm{ml}$ cylinder. Then distilled water was added into the cylinder and the added value was subtracted from the recorded value to get wet volume.

\section{Swelling capacity $\left(\mathrm{ml} \mathrm{seed}^{-1}\right)$}

$$
\begin{aligned}
& \text { Swelling capacity }(\mathrm{ml} \text { seed }-1) \\
& =\frac{[\text { Wet volume }- \text { Dry volume }]}{100-\text { Number of non }- \text { swelling seeds }}
\end{aligned}
$$

\section{Swelling index $(\%)$}

$$
\text { Swelling index }(\%)=\frac{\text { Wet volume }}{\text { Dry volume }}
$$

9. Cooking time (min): Hundred (100) wetted seeds were placed into $150 \mathrm{ml}$ boiling water in an Erlenmeyer on heater set at $220{ }^{\circ} \mathrm{C}$. For cooking controls, in every 10 minutes later, seed coat was removed and seeds were split into two halves, then disappearance of white spot in the middle of cotyledon was checked. As the white spot got smaller, control intervals were reduced initially to 5 minutes, then to 1 minute and the time passed until full disappearance of white spot was recorded as the cooking time.

\section{Hydration coefficient $(\%)$ :}

Hydration coefficient $(\%)=$ $\frac{[\text { Wet weight }- \text { Dry weight }]}{\text { Dryweight }} \times 100$

11. Unit weight $\left(\mathrm{g} \mathrm{ml}^{-1}\right)$ :

$$
\text { Unit weight }(\mathrm{g} / \mathrm{ml})=\frac{\text { Dry weight }}{\text { Dry volume }}
$$

12. Number of seeds destructed after cooking: Following the determination of cooking time, number of destructed seeds was counted.

\section{Statistical analysis}

Experimental data on technological characteristics of chickpea cultivars were subjected to analysis of variance by using JMP 13.0 (SAS Institute Inc., Cary, NC, USA) statistical software. Significant means were compared with the use of Tukey's test $(\mathrm{p} \leq 0.05)$ (Steel and Torrie, 1980; Chen et al., 2020).

\section{RESULTS AND DISCUSSION}

The greatest dry weight (49.35 g) was obtained from Ilgaz genotype and the lowest value $(37.17 \mathrm{~g})$ was obtained from Menemen 92 genotype. In terms of dry weight, Damla 89, Hasanbey, Inci, Izmir 92 and Kusmen cultivars were placed into the greatest statistical group (Table 3). Williams et al. (1983) reported dry weights of Kabuli type chickpeas as between 9.2 - $54.1 \mathrm{~g}$. Kaur et al. (2005) reported average dry weight as $21.94 \mathrm{~g}$. Seed weight and volume significantly influence consumer preferences and cooking quality (Sastry et al., 2019).

In terms of dry volumes, while Uzunlu $(41,67 \mathrm{ml})$ and Akca $(41,33 \mathrm{ml})$ cultivars had the greatest values, Menemen $92(25.67 \mathrm{ml})$ genotype had the lowest value (Table 3). Present findings were complying the results of Kaya et al. (2016). Kaur et al. (2005) reported average dry volume as $17.0 \mathrm{ml}$.

The greatest wet weight (103.85 g) was obtained from Ilgaz genotype and the lowest value (78.41 g) was obtained from Menenmen genotype. Besides, except for Damla 89, Hasanbey, Inci, Izmir 92 and Yasa 05 cultivars, the others were placed into the greatest group (Table 3). Kaya et al. (2016) reported wet weights as between 72.06-132.82 g. Wetting is an important issue for both domestic uses and industrial processes. In humans and ruminants, gas production through anaerobic digestion / fermentation of oligosaccharides by intestine bacteria with the partial leakage of substrate may be reduced (Wood and Harden, 2006). 
Table 3. Technological characteristics of chickpea cultivars

\begin{tabular}{|c|c|c|c|c|c|c|c|c|c|c|c|c|}
\hline & $\begin{array}{l}\text { Dry } \\
\text { weight } \\
\text { (g)* }\end{array}$ & $\begin{array}{l}\text { Dry volume } \\
(\mathrm{ml}) *\end{array}$ & $\begin{array}{l}\text { Wet } \\
\text { weight (g) }\end{array}$ & $\begin{array}{l}\text { Wet } \\
\text { volume } \\
(\%)^{*}\end{array}$ & $\begin{array}{l}\text { Water } \\
\text { absorption } \\
\text { capacity } \\
\text { (g/seed) } \\
\end{array}$ & $\begin{array}{l}\text { Water } \\
\text { absorption } \\
\text { index (\%) }\end{array}$ & $\begin{array}{l}\text { Hydration } \\
\text { coefficient } \\
(\%)\end{array}$ & $\begin{array}{l}\text { Swelling } \\
\text { capacity } \\
(\mathrm{ml} / \mathrm{seed})\end{array}$ & $\begin{array}{l}\text { Swelling } \\
\text { index }(\%)\end{array}$ & $\begin{array}{l}\text { Unit weight } \\
(\mathrm{g} / \mathrm{ml})\end{array}$ & $\begin{array}{l}\text { Cooking } \\
\text { time (min) }\end{array}$ & $\begin{array}{l}\text { Number of } \\
\text { destructed } \\
\text { seeds after } \\
\text { cooking }\end{array}$ \\
\hline Akca & $46,05 \mathrm{ab}$ & $41,33 \mathrm{a}$ & 99,79 a-d & $93,33 \mathrm{abc}$ & $0,537 \mathrm{a}$ & 1,17 & 117,00 & 0,520 b-g & $2,268 \mathrm{def}$ & $1,115 \mathrm{f}$ & 43,00 a-g & $8,67 \mathrm{ab}$ \\
\hline Akcin 91 & $44,48 \mathrm{abc}$ & $39,00 \mathrm{abc}$ & 94,14 a-e & 86,67 a-e & $0,497 \mathrm{abc}$ & 1,12 & 111,55 & $0,477 \mathrm{fg}$ & $2,222 \mathrm{def}$ & $1,140 \mathrm{def}$ & $35,67 \mathrm{fgh}$ & $10,67 \mathrm{ab}$ \\
\hline Aksu & $43,01 \mathrm{a}-\mathrm{d}$ & 36,67 a-e & $90,78 \mathrm{a}-\mathrm{f}$ & $84,00 \mathrm{~b}-\mathrm{f}$ & $0,478 \mathrm{a}-\mathrm{d}$ & 1,11 & 111,15 & $0,473 \mathrm{fg}$ & $2,292 \mathrm{c}-\mathrm{f}$ & $1,172 \mathrm{def}$ & $39,83 \mathrm{c}-\mathrm{h}$ & $7,33 \mathrm{ab}$ \\
\hline Aziziye 94 & $45,08 \mathrm{abc}$ & $32,33 \mathrm{~d}-\mathrm{h}$ & 94,70 a-e & 86,33 a-e & $0,496 \mathrm{abc}$ & 1,10 & 110,18 & $0,540 \mathrm{a}-\mathrm{f}$ & $2,688 \mathrm{ab}$ & $1,402 \mathrm{ab}$ & $46,00 \mathrm{abc}$ & $4,00 \mathrm{ab}$ \\
\hline Azkan & $46,75 \mathrm{ab}$ & $38,33 \mathrm{a}-\mathrm{d}$ & 101,22 & $95,33 \mathrm{ab}$ & $0,545 \mathrm{a}$ & 1,16 & 116,47 & $0,570 \mathrm{a}-\mathrm{d}$ & $2,498 b-f$ & $1,225 \mathrm{c}-\mathrm{f}$ & 44,00 a-e & $8,67 \mathrm{ab}$ \\
\hline Cevdetbey 98 & $47,33 \mathrm{ab}$ & $35,67 \mathrm{a}-\mathrm{g}$ & 99,82 a-d & $92,67 \mathrm{abc}$ & $0,525 \mathrm{ab}$ & 1,11 & 111,18 & $0,570 \mathrm{a}-\mathrm{d}$ & $2,615 a b c$ & $1,332 \mathrm{abc}$ & $37,83 \mathrm{~d}-\mathrm{h}$ & $6,67 \mathrm{ab}$ \\
\hline Cagatay & $44,09 \mathrm{abc}$ & $32,67 \mathrm{c}-\mathrm{h}$ & 93,33 a-e & 87,00 a-e & $0,493 \mathrm{a}-\mathrm{d}$ & 1,12 & 111,77 & $0,543 \mathrm{a}-\mathrm{f}$ & $2,667 \mathrm{ab}$ & $1,352 \mathrm{abc}$ & $39,33 \mathrm{c}-\mathrm{h}$ & $6,00 \mathrm{ab}$ \\
\hline Cakır & $44,50 \mathrm{abc}$ & $39,33 \mathrm{ab}$ & 95,24 a-e & 87,67 a-e & $0,507 \mathrm{abc}$ & 1,14 & 114,15 & $0,483 \mathrm{efg}$ & $2,228 \mathrm{def}$ & 1,128 ef & $45,33 \mathrm{a}-\mathrm{d}$ & $10,00 \mathrm{ab}$ \\
\hline Damla 89 & $41,76 \mathrm{bcd}$ & 29,67 gh1 & $86,86 \mathrm{def}$ & $80,67 \mathrm{def}$ & $0,451 \mathrm{bcd}$ & 1,08 & 107,68 & $0,510 \mathrm{c}-\mathrm{g}$ & $2,755 \mathrm{ab}$ & $1,433 \mathrm{a}$ & $46,17 \mathrm{abc}$ & $9,33 \mathrm{ab}$ \\
\hline Dikbas & $46,49 \mathrm{ab}$ & $35,67 \mathrm{a}-\mathrm{g}$ & 99,08 a-d & $91,67 \mathrm{a}-\mathrm{d}$ & $0,526 \mathrm{ab}$ & 1,13 & 113,02 & $0,560 \mathrm{a}-\mathrm{e}$ & $2,608 \mathrm{abc}$ & $1,322 a b c$ & $35,00 \mathrm{gh}$ & $1,33 \mathrm{~b}$ \\
\hline Er 99 & $43,64 \mathrm{abc}$ & 38,67 a-d & 91,88 a-e & 84,33 b-f & $0,482 \mathrm{a}-\mathrm{d}$ & 1,11 & 111,30 & $0,457 \mathrm{~g}$ & $2,183 \mathrm{f}$ & $1,125 \mathrm{ef}$ & $45,83 \mathrm{a}-\mathrm{d}$ & $7,33 \mathrm{ab}$ \\
\hline Gokce & $45,26 \mathrm{abc}$ & 34,33 b-g & 93,76 a-e & 87,33 a-e & 0,485 a-d & 1,07 & 107,13 & $0,530 \mathrm{~b}-\mathrm{g}$ & 2,548 a-d & $1,322 \mathrm{abc}$ & $46,33 \mathrm{abc}$ & $4,67 \mathrm{ab}$ \\
\hline Gulumser & $45,09 \mathrm{abc}$ & $33,00 \mathrm{~b}-\mathrm{h}$ & 92,31 a-e & 86,00 b-e & $0,472 \mathrm{a}-\mathrm{d}$ & 1,05 & 105,38 & 0,530 b-g & $2,623 \mathrm{abc}$ & $1,372 \mathrm{ab}$ & $43,67 \mathrm{a}-\mathrm{f}$ & $2,00 \mathrm{~b}$ \\
\hline Hasanbey & $42,57 \mathrm{bcd}$ & 38,00 a-e & 89,34 b-f & $83,00 \mathrm{c}-\mathrm{f}$ & $0,468 \mathrm{a}-\mathrm{d}$ & 1,10 & 109,82 & $0,450 \mathrm{~g}$ & $2,185 \mathrm{f}$ & $1,120 \mathrm{f}$ & $39,17 \mathrm{c}-\mathrm{h}$ & $12,00 \mathrm{ab}$ \\
\hline Ilgaz & $49,35 \mathrm{a}$ & 36,33 a-f & $103,85 \mathrm{a}$ & $98,00 \mathrm{a}$ & $0,545 \mathrm{a}$ & 1,10 & 110,40 & $0,617 \mathrm{a}$ & $2,705 a b$ & $1,362 a b c$ & $45,33 \mathrm{a}-\mathrm{d}$ & $8,00 \mathrm{ab}$ \\
\hline Isık 05 & $44,86 \mathrm{abc}$ & $35,67 \mathrm{a}-\mathrm{g}$ & 94,76 a-e & 87,67 a-e & $0,499 \mathrm{abc}$ & 1,12 & 111,55 & $0,520 \mathrm{~b}-\mathrm{g}$ & $2,473 \mathrm{~b}-\mathrm{f}$ & $1,262 \mathrm{~b}-\mathrm{e}$ & $47,17 \mathrm{abc}$ & $2,67 \mathrm{ab}$ \\
\hline Inci & $42,09 \mathrm{bcd}$ & $30,00 \mathrm{f}-1$ & $88,74 \mathrm{c}-\mathrm{f}$ & $82,67 \mathrm{c}-\mathrm{f}$ & $0,467 \mathrm{a}-\mathrm{d}$ & 1,11 & 110,63 & $0,527 \mathrm{~b}-\mathrm{g}$ & $2,770 \mathrm{ab}$ & $1,417 \mathrm{a}$ & $50,17 \mathrm{a}$ & $6,00 \mathrm{ab}$ \\
\hline Izmir 92 & $39,17 \mathrm{~cd}$ & $27,67 \mathrm{~h}_{1}$ & $82,80 \mathrm{ef}$ & 76,00 ef & $0,436 \mathrm{~cd}$ & 1,11 & 111,05 & $0,483 \mathrm{efg}$ & $2,763 \mathrm{ab}$ & $1,422 \mathrm{a}$ & 42,67 a-h & $12,00 \mathrm{ab}$ \\
\hline Kusmen & $42,75 \mathrm{bcd}$ & 33,67 b-h & 91,95 a-e & 85,33 b-e & $0,492 \mathrm{a}-\mathrm{d}$ & 1,15 & 114,92 & $0,517 \mathrm{~b}-\mathrm{g}$ & $2,542 \mathrm{a}-\mathrm{e}$ & $1,275 \mathrm{bcd}$ & $50,00 \mathrm{a}$ & $3,33 \mathrm{ab}$ \\
\hline Menemen 92 & $37,17 \mathrm{~d}$ & 25,671 & $78,41 \mathrm{f}$ & $73,00 \mathrm{f}$ & $0,412 \mathrm{~d}$ & 1,11 & 111,10 & $0,473 \mathrm{fg}$ & $2,867 \mathrm{a}$ & $1,458 \mathrm{a}$ & 41,83 b-h & $14,67 \mathrm{a}$ \\
\hline Osmanbey & $45,95 \mathrm{ab}$ & 33,00 b-h & 98,57 a-d & 92,00 a-d & $0,526 \mathrm{ab}$ & 1,16 & 115,60 & $0,590 \mathrm{abc}$ & $2,803 \mathrm{ab}$ & $1,395 \mathrm{ab}$ & 36,33 e-h & $2,67 \mathrm{ab}$ \\
\hline Sarı 98 & $47,73 \mathrm{ab}$ & $36,00 \mathrm{a}-\mathrm{g}$ & $102,09 \mathrm{ab}$ & $95,33 \mathrm{ab}$ & $0,544 \mathrm{a}$ & 1,14 & 113,85 & $0,593 \mathrm{ab}$ & $2,655 \mathrm{ab}$ & $1,328 \mathrm{abc}$ & $49,00 \mathrm{ab}$ & $4,67 \mathrm{ab}$ \\
\hline Seckin & 43,21 a-d & 34,33 b-g & 90,86 a-f & 84,00 b-f & 0,477 a-d & 1,10 & 110,22 & $0,497 \mathrm{~d}-\mathrm{g}$ & 2,477 b-f & $1,273 \mathrm{bcd}$ & 44,83 a-d & $8,00 \mathrm{ab}$ \\
\hline Sezenbey & $45,08 \mathrm{abc}$ & $33,67 \mathrm{~b}-\mathrm{h}$ & 96,18 a-d & 90,67 a-d & $0,511 \mathrm{abc}$ & 1,13 & 113,47 & $0,570 \mathrm{a}-\mathrm{d}$ & $2,720 \mathrm{ab}$ & $1,350 \mathrm{abc}$ & 44,00 a-e & $6,67 \mathrm{ab}$ \\
\hline Uzunlu 99 & $46,22 \mathrm{ab}$ & $41,67 \mathrm{a}$ & 98,88 a-d & $92,00 \mathrm{a}-\mathrm{d}$ & $0,527 \mathrm{ab}$ & 1,14 & 114,05 & $0,503 \mathrm{~d}-\mathrm{g}$ & $2,208 \mathrm{ef}$ & $1,108 \mathrm{f}$ & $34,83 \mathrm{~h}$ & $10,00 \mathrm{ab}$ \\
\hline Yasa 05 & 43,35 a-d & $31,67 \mathrm{e}-1$ & 89,91 b-f & $82,33 \mathrm{c}-\mathrm{f}$ & 0,466 a-d & 1,07 & 107,42 & $0,507 \mathrm{~d}-\mathrm{g}$ & $2,612 a b c$ & $1,372 \mathrm{ab}$ & $40,00 \mathrm{c}-\mathrm{h}$ & $12,00 \mathrm{ab}$ \\
\hline Zuhal & $43,59 \mathrm{abc}$ & $32,67 \mathrm{c}-\mathrm{h}$ & 92,88 a-e & 87,33 a-e & $0,493 \mathrm{a}-\mathrm{d}$ & 1,13 & 113,15 & $0,547 \mathrm{a}-\mathrm{f}$ & $2,680 \mathrm{ab}$ & $1,338 \mathrm{abc}$ & $41,83 \mathrm{~b}-\mathrm{h}$ & $5,33 \mathrm{ab}$ \\
\hline \multicolumn{13}{|c|}{ Averages } \\
\hline 1st year & 45,23 & 35,06 & $96,55 \mathrm{~A}$ & $89,78 \mathrm{~A}$ & $0,513 \mathrm{~A}$ & $1,14 \mathrm{~A}$ & $113,60 \mathrm{~A}$ & $0,547 \mathrm{~A}$ & 2,586 & 1,302 & $52,43 \mathrm{~A}$ & $4,15 \mathrm{~B}$ \\
\hline 2nd year & 43,42 & 34,32 & $91,02 \mathrm{~B}$ & $84,47 \mathrm{~B}$ & $0,476 \mathrm{~B}$ & $1,10 \mathrm{~B}$ & $109,75 \mathrm{~B}$ & $0,501 \mathrm{~B}$ & 2,500 & 1,285 & $33,14 \mathrm{~B}$ & $10,27 \mathrm{~A}$ \\
\hline \multicolumn{13}{|c|}{ F values } \\
\hline Year $(\mathbf{Y})$ & 5,338 & 1,329 & $14,527 *$ & $15,221^{*}$ & $25,045^{*}$ & $11,633^{*}$ & $11,633^{*}$ & $21,799 *$ & 7,316 & 2,272 & $71,396^{*}$ & $21,238^{*}$ \\
\hline Genotype (G) & $4,642 * *$ & $10,756 * *$ & $5,611^{* *}$ & $6,748 * *$ & $4,937 * *$ & 1,150 & 1,150 & $8,134 * *$ & $11,602 * *$ & $18,126^{* *}$ & $9,892 * *$ & $2,341 *$ \\
\hline Y X G & $4,352 * *$ & $4,842^{* * *}$ & $3,899 * *$ & $4,410 * *$ & $2,884 * *$ & 1,556 & 1,556 & $3,377 * *$ & $2,872 * *$ & $4,193^{* *}$ & $10,660^{* * *}$ & $2,088^{*}$ \\
\hline
\end{tabular}


Wet volumes of the chickpea cultivars varied between $98.00 \%$ (Ilgaz) - 73.00\% (Menemen 92). As can be seen in Table 3, 16 cultivars were placed into the greatest groups. Present findings similar with the values of Kaya et al. (2016).

In terms of water absorption capacity, while Menemen 92 genotype had the lowest value $(0.412 \mathrm{~g} / \mathrm{seed})$, except for Damla $89\left(0.451 \mathrm{~g} \mathrm{seed}^{-1}\right)$ and Izmir $92\left(0.436 \mathrm{~g} \mathrm{seed}^{-1}\right)$ cultivars, the rest were placed into the same group with Azkan and Ilgaz $\left(0.545 \mathrm{~g} \mathrm{seed}^{-1}\right)$ which had the greatest values (Table 3). Present findings on water absorption capacity were greater than the values of Yalcin et al. (2018), but similar with the values of Ozer et al. (2010); Sastry et al. (2019), Kaya et al. (2016).

Water absorption index and hydration coefficients of the cultivars were not found to be significant. In terms of both parameters, Akca genotype had the greatest values and Gulumser genotype had the lowest values. Water absorption index values varied between $1.17-1.05 \%$ and hydration coefficients varied between 117.0 and $105.38 \%$ (Table 3). Present water absorption capacity values were similar with the values of Sastry et al. (2019), Kaya et al. (2016)

The greatest swelling capacity $\left(0.617 \mathrm{ml} \mathrm{seed}^{-1}\right)$ was obtained from Ilgaz genotype and the lowest value $(0.450$

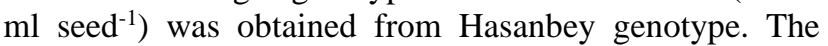
others had values in between them (Table 3). Present swelling capacity values were greater than the values of Ozer et al. (2010); Sastry et al. (2019), but similar with the values of Kaya et al. (2016).

Swelling index values varied between 2.867 and $2.183 \%$. Menemen 92 genotype had the greatest value and 16 other cultivars were placed into the same group (Table 3 ). Present swelling index values were greater than the values of Sastry et al. (2019), but similar with the values of Kaya et al. (2016).

Unit weight expresses seed weight per unit volume and the greatest values were respectively obtained from Menemen $92\left(1.458 \mathrm{~g} \mathrm{ml}^{-1}\right)$, Damla $89\left(1.433 \mathrm{~g} \mathrm{ml}^{-1}\right)$, Izmir $92\left(1.422 \mathrm{~g} \mathrm{ml}^{-1}\right)$ and Inci $\left(1.417 \mathrm{~g} \mathrm{ml}^{-1}\right)$ cultivars. Akca (1.115 $\left.\mathrm{g} \mathrm{ml}^{-1}\right)$, Hasanbey $\left(1.120 \mathrm{~g} \mathrm{ml}^{-1}\right)$ and Uzunlu 99 $\left(1.108 \mathrm{~g} \mathrm{ml}^{-1}\right)$ cultivars were placed into the lowest unit weight group (Table 3). Bibi et al. (2007) reported unit weights as between $1.17-1.32 \mathrm{~g} \mathrm{ml}^{-1}$ and Kaur et al. (2005) reported average unit weight as $1.29 \mathrm{~g} \mathrm{ml}^{-1}$.

In terms of cooking times, the shortest cooking time (34.83 $\mathrm{min}$ ) was observed in Uzunlu genotype and the longest cooking times were observed in Inci and Kusmen cultivars (50.17 and $50.00 \mathrm{~min}$, respectively). Akca, Aziziye 94, Azkan, Cakır, Er 99, Gokce, Gulumser, Ilgaz, Isık 05, Izmir 92, Sar1 98, Seckin and Sezenbey cultivars were placed into the longest cooking time group (Table 3). Present cooking times similar with the values of Ozer et al. (2010). Cooking time is a significant parameter used for the assessment of cooking quality of pulses. Cooking time is also an important parameter for energy requirements in developing countries (Nadeem et al., 2020). The longer the cooking time is, the greater the nutrient loss and energy consumptions are (Haileslassie et al. (2019). Wang, et al. (2010) reported that cooking influenced nutritional composition of chickpeas.

In terms of number of destructed seeds, the lowest destructions were observed in Dikbas and Gulumser cultivars and the other cultivars were placed into the same group with Menemen 92 genotype which had the greatest destruction (14.67 seeds) (Table 3). Besides cooking time, kernel texture after cooking is also another important quality trait of pulses. Cooking results in various physicochemical changes in pulses such as gelatinization of starch, denaturation of protein, relative decomposition of polysaccharides and softening and destruction of jointing material of cotyledons (Bishnoi and Khetarpaul, 1993).

When the effects of years on technological characteristics of chickpea cultivars were assessed, it was observed that effects of years on dry volume and unit weights were not significant, but effects of years on the other characteristics were found to be significant. Except for number of destructed seeds after cooking, the greatest values of all parameters were observed in the first year. When the entire findings were assessed together, it was observed that except for water absorption index and hydration capacity, significant variations were observed in all the other characteristics of the cultivars. Such a case was also reported by several other researchers (Bibi et al., 2007). As explained in detail above, present findings were similar with the results of some literatures and significantly different from the others. Such differences were mostly attributed to climate and soil conditions, cultivars and growing techniques. Thusly, Yalcin et al. (2018) reported significant year $\mathrm{x}$ cultivar interactions for water absorption capacity and hydration coefficient; Koksel et al. (1993) reported significant effects of growing conditions on entire technological characteristics of chickpeas.

Eigen values, variance, total variance, significance levels and component weights for investigated characteristics of chickpea cultivars are provided in Table 4. In terms of investigated characteristics, 9 independent principle components (PC) with eigen values greater than 0 were identified. Eigen values of these principle components varied between 0.0001 and 5.92 explained $100 \%$ of total variation. For efficient use of principle component analysis and accurate interpretation of the results, the first two or three principle components should explain at least $25 \%$ of total variations (Mohammadi and Prasanna, 2003). While identification of number of principle components, $2 / 3$ of total variance was taken into consideration. Present analysis revealed that $100 \%$ of total variance was explained. Considering the $2 / 3$ of total variance as $66.66 \%$, two principle component axes explained $75.12 \%$ of total variation. Component weights were considered to be significant when the value is greater than 0.3 (Gozen, 2008). Weights of investigated characteristics on principle components (Table 4) revealed that the wet weight, wet volume and water absorption capacity characteristics with the greatest weights on PC1 axis explained $49.33 \%$ of total variation. The swelling capacity, swelling index and unit 
weight characteristics with the greatest weights on PC2 explained $25.79 \%$ of total variation. In biplot analysis, narrowing vector angles indicate closeness of the characteristics and enlarging vector angles indicate weakened relationships among the characteristics (Yan, 2014). Wet weight, wet volume, dry weight and water absorption capacity had close relationships with each other. Besides, unit weight and swelling capacity had greater impact on PC2, thus had positive correlations with each other. According to present findings, dry weight, dry volume, wet volume and water absorption characteristics on PC1 and swelling capacity, swelling index and unit weight characteristics on PC2 were found to be sufficient in definition of technological characteristics of chickpea cultivars (Fig. 1).

Table 4. Eigen values, variance, total variance, probabilities for investigated characteristics and Principle component analysis results

\begin{tabular}{|c|c|c|c|c|c|c|c|c|c|}
\hline & PC1 & PC2 & PC3 & PC4 & PC5 & PC6 & PC7 & PC8 & PC9 \\
\hline Eigen value & 5,9194 & 3,0944 & 1,4549 & 0,9735 & 0,5343 & 0,0187 & 0,0038 & 0,0009 & 0,0001 \\
\hline Variance $(\%)$ & 49,328 & 25,786 & 12,124 & 8,113 & 4,452 & 0,156 & 0,032 & 0,007 & 0,001 \\
\hline Total variance $(\%)$ & 49,328 & 75,115 & 87,239 & 95,351 & 99,804 & 99,96 & 99,992 & 99,999 & 100 \\
\hline Prob $>$ ChiSq & $<.0001 *$ & $<.0001 *$ & $<.0001 *$ & $<.0001 *$ & $<.0001 *$ & null & null & null & null \\
\hline
\end{tabular}

Principle component analysis results

\begin{tabular}{|c|c|c|c|c|c|}
\hline Characteristics & PC1 & PC2 & PC3 & PC4 & PC5 \\
\hline Dry weight (gr) & 0.36961 & 0.13948 & -0.28275 & -0.06375 & 0.12470 \\
\hline Dry volume $(\mathrm{ml}) *$ & 0.32384 & -0.32118 & -0.19132 & 0.06359 & 0.03591 \\
\hline Wet weight (gr) & 0.39667 & 0.10737 & -0.12483 & -0.04212 & 0.10990 \\
\hline Wet volume $(\%) *$ & 0.39398 & 0.12734 & -0.09310 & -0.04477 & 0.15274 \\
\hline $\begin{array}{l}\text { Water absorption capacity } \\
\text { (g/seed) }\end{array}$ & 0.40533 & 0.07992 & -0.00220 & -0.02435 & 0.09651 \\
\hline Water absorption index (\%) & 0.26103 & -0.09692 & 0.61902 & 0.07386 & -0.09415 \\
\hline Hydration coefficient (\%) & 0.26103 & -0.09692 & 0.61902 & 0.07386 & -0.09415 \\
\hline Swelling capacity $(\mathrm{ml} / \mathrm{seed})$ & 0.23210 & 0.45620 & 0.04791 & -0.11623 & 0.17021 \\
\hline Swelling index $(\%)$ & -0.14451 & 0.50269 & 0.22008 & -0.14105 & 0.08268 \\
\hline Unit weight $(\mathrm{g} / \mathrm{ml})$ & -0.19792 & 0.48512 & 0.09941 & -0.13993 & 0.06338 \\
\hline Cooking time (min) & -0.06594 & 0.17020 & -0.00443 & 0.91594 & 0.35632 \\
\hline $\begin{array}{l}\text { Number of destructed seeds } \\
\text { after cooking }\end{array}$ & -0.16467 & -0.31519 & 0.17940 & -0.29099 & 0.86829 \\
\hline
\end{tabular}

Seed weight, seed volume, swelling index and hydration capacity are related to cooking time and such relationships result in long, medium and short cooking times of chickpea cultivars (Williams et al., 1983). Correlations for technological characteristics of chickpea cultivars grown under natural conditions and scatter plot of the cultivars are presented in Figure 2. The cultivars clustered in three main colors in the dendrogram generated with the colored dots for the cultivars within a colored elliptical circles were similar with each other. Dry weight had highly significant positive correlations with wet weight $(\mathrm{r}=0.9776)$, wet volume $(\mathrm{r}=0.9653)$ and water absorption capacity $(\mathrm{r}=0.9317)$. Wet volume had highly significant negative correlations with swelling index $(\mathrm{r}=-0.8437)$ and unit weight $(\mathrm{r}=-0.8966)$. Water absorption capacity had highly significant positive correlations with wet volume $(\mathrm{r}=0.9834)$ and wet weight $(\mathrm{r}=0.9873)$. The greatest correlations were observed between water absorption index and hydration coefficient $(\mathrm{r}=1.000)$. There was a highly significant correlation between swelling index and unit weight ( $r=0.9774)$. Cooking time did not exhibit significant correlations with the other parameters. There were significant correlations between number of destructed seeds after cooking and swelling capacity ( $\mathrm{r}=-0.5471)$ (Fig. 2 and supportive Fig. 1). Gil et al. (1996) reported that seed weight had significant positive correlations with hydration capacity and swelling capacity of the chickpea cultivars. Williams et al. (1983) and Singh et al. (1992) also reported significant positive correlations between seed weight and hydration capacity of chickpeas. 

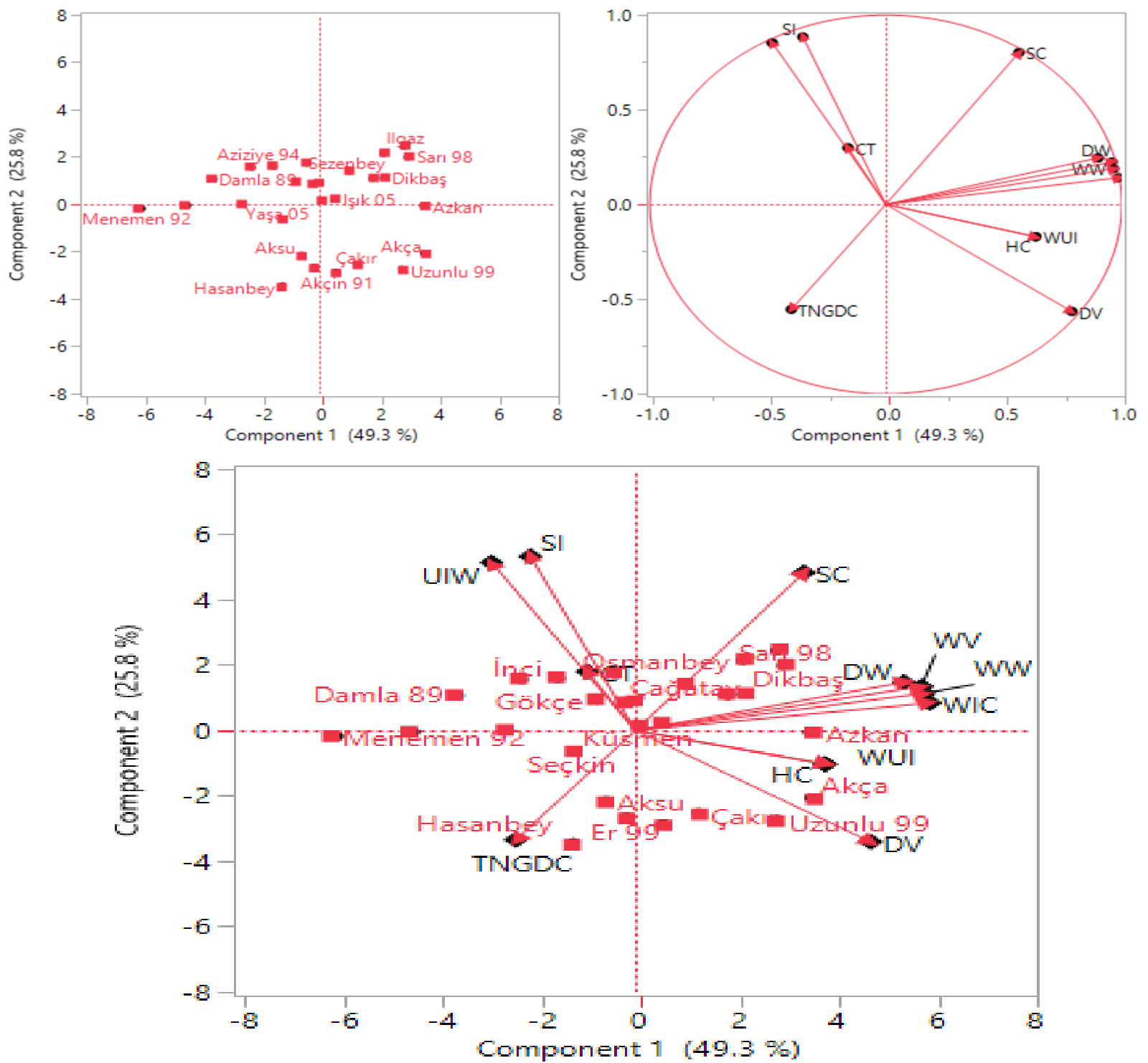

Fig. 1. Principle component analysis for technological characteristics of chickpea cultivars

Dry weight:DW, dry volume:DV, wet weight:WW, wet volume:WV, water absorption capacity:WIC, water absorption index:WUI, hydration coefficient:HC, swelling capacity:SC, swelling index:SI, unit weight:UIW cooking time:CT, number of destructed seeds after cooking:TNGDC

The dendrogram generated for technological characteristics of chickpea cultivars grown under natural conditions is composed of three sub-clusters under two main clusters. The primary cultivars with similar technological characteristics were identified as Cagatay and Zuhal. The Menemen 92, Izmir 92, Gulumser, Gokce, Inci, Yasa 05 and Damla 89 cultivars were placed into the first main cluster. Also, Izmir 92 and Menemen 92 cultivars were clustered in the first sub-cluster of the first main cluster and exhibited significant differences from the other cultivars. The Akca, Azkan, Cakır, Uzunlu 99, Akcin 91, Hasanbey, Aksu, Er 99 and Seckin cultivars were placed into the second sub-cluster of the second main cluster, the remaining cultivars (Aziziye 94, Isık 05, Kusmen, Cagatay, Zuhal, Sezenbey, Cevdetbey 98, Dikbas, Osmanbey, Ilgaz and Sar1 98) were placed into the first sub-cluster of the second main cluster (Fig. 2). 

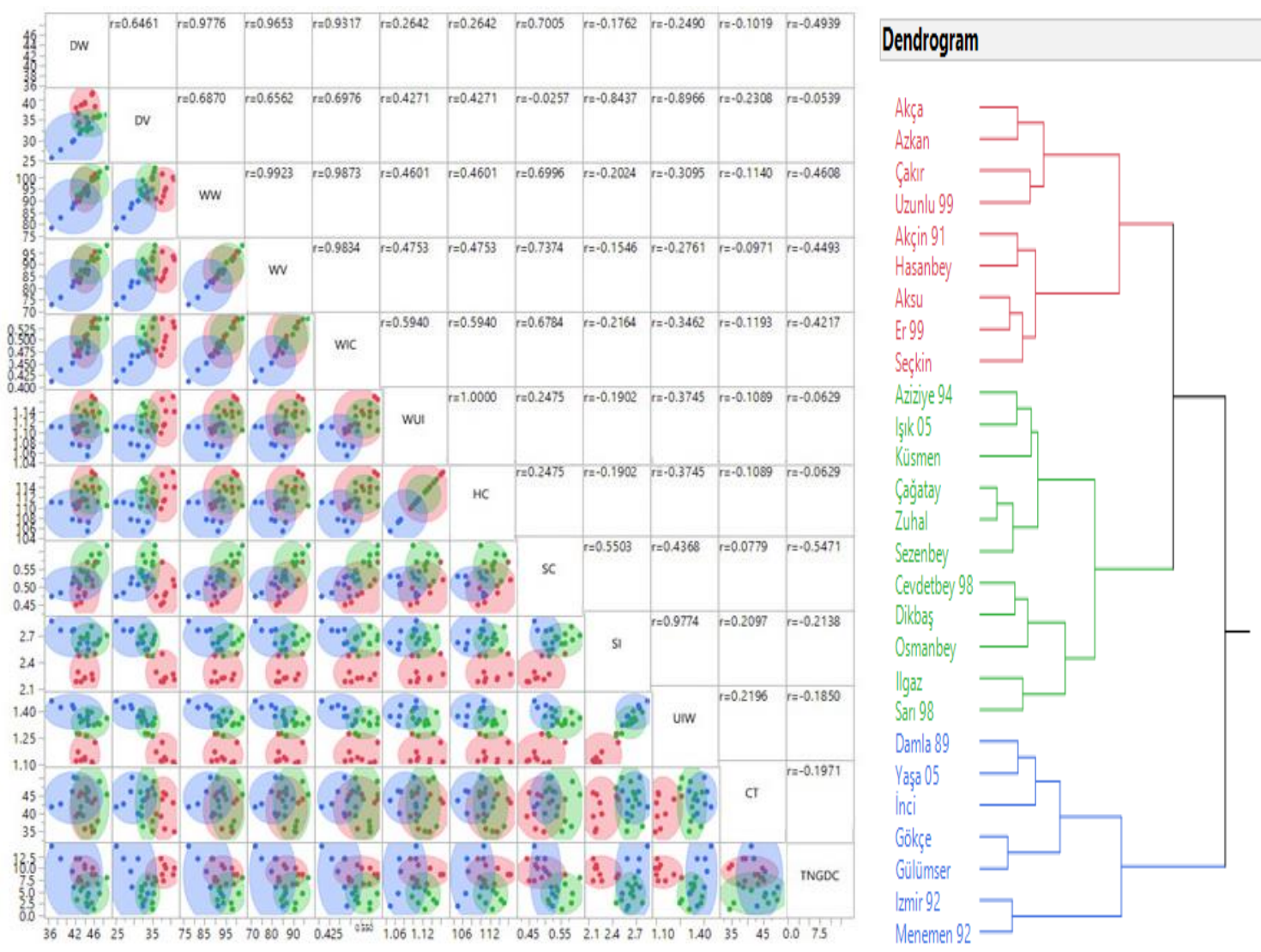

Fig. 2. Correlation coefficients, scatter plots and dendrogram for technological characteristics of chickpea cultivars

Dry weight:DW, dry volume:DV, wet weight:WW, wet volumeWV, water absorption capacity:WIC, water absorption index:WUI, hydration coefficient:HC, swelling capacity:SC, swelling index:SI, cooking time:CT, number of destructed seeds after cooking:TNGDC

\section{CONCLUSIONS}

Technological characteristics of 27 Kabuli cultivars were investigated in this study and Dikbas genotype had low cooking time and number of destructed seeds after cooking and high values for the other characteristics. Apart from cooking time, for the other characteristics, Cagatay, Osmanbey and Cevdetbey cultivars with low cooking time and high wet weight, wet volume, water absorption capacity, water absorption index, swelling capacity could also be recommended to be cultivated under natural farming conditions without the use of any fertilizers and chemicals since they were placed into the same statistical group and clustered in the same cluster with Dikbas genotype.

\section{ACKNOWLEDGEMENTS}

This study was supported by Turkish Scientific Research Council (TUBITAK) with the project number of 1190226.

\section{LITERATURE CITED}

Bibi, N., A. B. Khattak, G. S. Khattak, Z. Mehmood, I. Ihsanullah. 2007. Quality and consumers acceptability studies and their inter-relationship of newly evolved desi type chickpea cultivars (Cicer arietinum L.). Quality evolution of new chickpea cultivars. International Journal of Food Science \& Technology 42(5): 528-534.

https://doi.org/10.1111/j.1365-2621.2006.01246.x
Bishnoi, S., N. Khetarpaul. 1993. Effect of domestic processing and cooking methods on in-vitro starch digestibility of different pea cultivars (Pisum sativum). Food Chemistry 47(2): $\quad$ 177-182. $\quad$ https://doi.org/10.1016/03088146(93)90240-G

Chavan, J. K., S. S. Kadam, D. K. Salunkhe, L. R. Beuchat. 1987. Biochemistry and technology of chickpea (Cicer arietinum L.) seeds. Critical Reviews in Food Science \& $\begin{array}{llr}\text { Nutrition } & 25(2): & \text { 107-158. }\end{array}$ https://doi.org/10.1080/10408398709527449

Chen, C., S. Chen, R. K. Jha, L. Cotrozzi, C. Nali, G. Lorenzini, L. Ma. 2020. Phenol metabolism of two cultivars of durum wheat (Triticum durum Desf.) as affected by ozone and flooding stress. Journal of Agronomy and Crop Science 206(3): 338-351. https://doi.org/10.1111/jac.12394

Patanè, C., E. Iacoponi, S.A. Raccuia. 2004 Physicochemical characteristics, water absorption, soaking and cooking properties of some Sicilian populations of chickpea (Cicer arietinum L.), International Journal of Food Sciences and Nutrition 55(7): 547-554, https://doi.org/10.1080/09637480400015836

de Almeida Costa, G. E. K. da Silva Queiroz-Monici, S. M. P. M. Reis, A. C. de Oliveira. 2006. Chemical composition, dietary fibre and resistant starch contents of raw and cooked pea, common bean, chickpea and lentil legumes. Food Chemistry 94(3): 327-330. https://doi.org/10.1016/j.foodchem.2004.11.020

Gil, J., S. Nadal, D. Luna, M. T. Moreno, A. D. Haro. 1996. Variability of some physico-chemical characters in Desi and Kabuli chickpea types. Journal of the Science of Food and Agriculture 71(2): 179-184. 
https://doi.org/10.1002/(SICI)10970010(199606)71:2<179::AID-JSFA566>3.0.CO;2-7

Gozen, V. 2008. Morphologic Characterization in Hybrid Greenhouse Cucumber (Cucumis sativus L.) Breedıng and Determination of Appropriate Hybrid Combinations and Hybrid Seed Quality. Ankara University Graduate School of Natural and Applied Science Department of Horticulture, Ph.D. Thesis, 185s, Ankara.

Gulumser, A., H. Bozoglu, E. Pesken. 2008. Edible legumes (Application Book), 2nd edition, OMU Faculty of Agriculture, Samsun.

Haileslassie, H. A., C.J. Henry, R.T. Tyler. 2019. Impact of pretreatment (soaking or germination) on nutrient and antinutrient contents, cooking time and acceptability of cooked red dry bean (Phaseolus vulgaris L.) and chickpea (Cicer arietinum L.) grown in Ethiopia. International Journal of Food Science \& Technology, 54(8): 2540-2552. https://doi.org/10.1111/ijfs.14165

Jukanti, A. K., P.M. Gaur, C.L.L. Gowda, R.N. Chibbar. 2012. Nutritional quality and health benefits of chickpea (Cicer arietinum L.): a review. British Journal of Nutrition 108(S1): S11-S26. https://doi.org/10.1017/S0007114512000797

Kaur, M., N. Singh, N.S. Sodhi. 2005. Physicochemical, cooking, textural and roasting characteristics of chickpea (Cicer arietinum L.) cultivars. Journal of Food Engineering 69(4): 511-517. https://doi.org/10.1016/j.jfoodeng.2004.09.002

Koksel, H , A. Atl1, A . Dag. 1992. A study on the influence of genotype and environment on technological properties of chickpea. Journal of Field Crops Central Research Institute, 2 (1), Retrieved from https://dergipark.org.tr/tr/pub/tarbitderg/issue/11527/137313

Mohammadi, S.A. and B.M. Prasanna. 2003. Analysis of Genetic Diversity in Crop Plants Salient Statistical Tools and Considerations. Crop Science 43: 1235-1248. https://doi.org/10.2135/cropsci2003.1235

Kaya, M., R. Karaman, M. Capar. 2016. Evaluation for Some Quality and Technological Properties of Grown Chickpea Cultivars in The Lake District Provincials. Journal of Field Crops Central Research Institute 25 (Special issue-1): 184190. https://doi.org/10.21566/tarbitderg.280377

Nadeem, M. A., Y. Cilesiz, F. Ali, F. S. Baloch, T. Karakoy. 2020. Investigation of Quality and Cooking Traits Diversity in a Global Common Bean Germplasm. Global Journal of Botanical Science 8: 21-29. https://doi.org/10.12974/2311$\underline{858 X .2020 .08 .3}$

Ozer S, T. Karakoy, F. Toklu, F.S. Baloch, B. Kilian, H. Ozkan. 2010. Nutritional and physicochemical variation in Turkish kabuli chickpea (Cicer arietinum L.) landraces. Euphytica 175: 237-249. https://doi.org/10.1007/s10681-010-0174-3

Sastry, D. V. S. S. R., H. D. Upadhyaya, T. R. Srinivas. 2019. Variation for seed physical and hydration properties of chickpea (Cicer arietinum L.) mini core collection and their relevance to conservation and utilization. Plant Genetic Resources: Characterization and Utilization (TSI): 1-14. https://doi.org/10.1017/S1479262119000030

Savage, G. P., G. E. Savage, A. C. Russell, J. P. Koolaard. 2001. Search for predictors of cooking quality of marrowfat pea
(Pisum sativum L.) cultivars, Journal of the Science of Food and Agriculture 81: 701-705. https://doi.org/10.1002/jsfa.860

Singh, N., N. Kaur, J. C. Rana, S. K. Sharama. 2010. Diversity in seed and flour properties in field pea (Pisum sativum) germplasm, Food Chemistry, 122: 518-525 https://doi.org/10.1016/j.foodchem.2010.02.064

Singh, N., K. S. Sekhon, U. Bajwa, S. Gopal. 1992. Cookıng and Parching Characteristics of Chickpea (Cicer arietinum L.). Journal of Food Science and Technology-Mysore 29(6): 347-350.

Steel, R.G.D. and J.H. Torrie. 1980. Principles and Procedures of Statistics. McGaw-Hill Book Company, Inc. N.Y.

Ramakrishna Rani, V.P.J., P. R. Rao. 2006. Anti-nutritional factors during germination in indian bean (Dolichos lablab 1.) seeds, World Journal of Dairy Food Sciences vol. 1, no. 1, pp. 6-11.

Wang, E., P. Martre, Z. Zhao, F. Ewert, A. Mariorano, R.P. Rotter, B.A. Kimball, M.L. Ottman, G.W. Wall, J.W. White, M.P. Reynolds, P.D. Alderman, P.K. Aggarwal, J. Anothai, B. Basso, C. Biernath, D. Cammarano, A.J.Challinor, G.D. Sanctis, J. Doltra, B. Dumont, E. Fereres, M. Garcia-Villa, S. Gayler, G. Hoogenboom, L.A. Hunt, R.C. Izaurralde, M. Jabloun, C.D. Jones, K.C. Kersebaum, A.Koehler, L. Liu, C. Muller, S.N. Kumar, C. Nendel, G. O'Leary, J.E. Olesen, T.Palosuo, E. Priesack, E.E. Rezaei, D. Ripoche, A.C. Ruane, M. A. Semenov, L.Shcherbak, C. Stockle, P. Stratonovitch, T. Streck, I. S2017. "The uncertainty of crop yield projecupit, F. Tao, P. Thorburn, K. Waha, D. Wallach, Z. Wang, J. Wolf, Y. Zhu. The uncertainty of crop yield projections is reduced by improved temperature response functions." Nature plants 3.8: $1-13$.

Doi: 10.1038/nplants.2017.102.

Wang, N., D. W. Hatcher, R. T. Tyler, R. Toews, E. J. Gawalko. 2010. Effect of cooking on the composition of beans (Phaseolus vulgaris L.) and chickpeas (Cicer arietinum L.). Food Research International 43(2): 589-594. https://doi.org/10.1016/j.foodres.2009.07.012

Williams, P. C., H. Nakoul, K. B. Singh. 1983. Relationship between cooking time and some physical characteristics in chickpeas (Cicer arietinum L.). Journal of the Science of Food and Agriculture 34(5): 492-496. https://doi.org/10.1002/jsfa.2740340510

Wood, J. A. and S. Harden. 2006. A method to estimate the hydration and swelling properties of chickpeas (Cicer arietinum L.). Journal of Food Science 71(4): E190E195. https://doi.org/10.1111/j.1750-3841.2006.00009.x

Yalcin, F., Z. Mut, O. D. Erbas Kose. 2018. Determination of Suitable Chickpea (Cicer arietinum L.) Varieties to Provide High Yield in Afyonkarahisar and Yozgat Conditions. Journal of Agricultural Faculty of Gaziosmanpasa University 35(1): 46-59. https://doi.org/10.13002/jafag4367

Yan W. 2014. Crop variety trials: Data management and analysis. John Wiley \& Sons.

Zia-Ul-Haq, M., Iqbal, S.,Ahmad, S. Imran, M. A. Niaz, M. I. Bhanger. 2007. Nutritional and compositional study of desi chickpea (Cicer arietinum L.) cultivars grown in Punjab, Pakistan.FoodChemistry 105(4):1357-1363. https://doi.org/10.1016/j.foodchem.2007.05.004 
